\title{
Bacterial metabolism of 5-aminosalicylic acid: enzymic conversion to L-malate, pyruvate and ammonia
}

\author{
AndREAS StOlz* and Hans-JoACHIM KnACKMUSS \\ Institute für Mikrobiologie der Universität Stuttgart, Azenbergstr. 18, 7 Stuttgart 1, Germany
}

(Received 2 September 1992; revised 11 November 1992; accepted 16 December 1992)

\begin{abstract}
5-Aminosalicylate (5AS) was converted to L-malate, pyruvate and ammonia by cell-free extracts from Pseudomonas Sp. BN9 in the presence of glutathione. In the absence of glutathione, 5AS was oxidized to the ringfission product cis-4-amino-6-carboxy-2-oxo-hexa-3,5-dienoate (cis-ACOHDA). Glutathione catalysed the spontaneous isomerization of cis-ACOHDA to its trans-isomer. The same reaction was catalysed by light and by acidic conditions. trans-ACOHDA was enzymically deaminated to fumarylpyruvate (trans-2,4-dioxo-5hexenoate). The trans-ACOHDA hydrolase was induced after growth of Pseudomonas sp. BN9 with 5AS, but not after growth with acetate or nutrient broth. At the fumarylpyruvate stage, the metabolism of 5AS converged with a pathway described for the degradation of gentisate. Fumarylpyruvate was cleaved by Pseudomonas sp. BN9 to fumarate and pyruvate.
\end{abstract}

\section{Introduction}

5-Aminosalicylate (5AS) was identified as an intermediate in the degradation of 6-aminonaphthalene-2sulphonic acid (6A2NS) and related azo dyes by a mixed bacterial community (Nörtemann et al., 1986; Haug et al., 1991). Two bacterial strains participated in the total degradation of 6A2NS. Pseudomonas sp. BN6 converted 6A2NS into an equimolar amount of 5AS and utilized only the pyruvate released from the breakdown of the sulphonated aromatic ring. 5AS was degraded after interspecies metabolite transfer by Pseudomonas sp. BN9. In contrast with the generally known degradative pathways for aromatic compounds, 5AS was subject to direct ring fission without the intermediate formation of a dihydroxylated aromatic compound, being cleaved by a dioxygenase in Pseudomonas sp. BN9 to cis-4-amino-6-carboxy-2-oxo-hexa-3,5-dienoate (Stolz et al., 1992). The further metabolism of cis-4-amino-6carboxy-2-oxo-hexa-3,5-dienoate is described here.

\section{Methods}

Bacterial strains and media. Pseudomonas sp. BN9 has been isolated and described by Nörtemann et al. (1986). Pseudomonas acidovorans

*Author for correspondence. Tel. 711121 1227; fax 7111211213.

Abbreviations: ACOHDA, 4-amino-6-carboxy-2-oxo-hexa-3,5dienoate; 6A2NS, 6-aminonaphthalene-2-sulphonate; 5AS, 5-aminosalicylate.
DSM 50053 was kindly provided by Dr M. Schlömann, Stuttgart. Bacteria were cultivated in a mineral medium which contained, per litre: $6 \mathrm{~g} \mathrm{Na}_{2} \mathrm{HPO}_{4} .2 \mathrm{H}_{2} \mathrm{O}, 1 \mathrm{~g} \mathrm{KH}_{2} \mathrm{PO}_{4}, 1 \mathrm{~g}\left(\mathrm{NH}_{4}\right)_{2} \mathrm{SO}_{4}, 50 \mathrm{mg}$ $\mathrm{Ca}\left(\mathrm{NO}_{3}\right)_{2} \cdot 4 \mathrm{H}_{2} \mathrm{O}, 200 \mathrm{mg} \mathrm{MgSO}_{4} \cdot 7 \mathrm{H}_{2} \mathrm{O}, 10 \mathrm{mg} \mathrm{Fe}(\mathrm{III}) / \mathrm{NH}_{4} /$ citrate and $0.1 \mathrm{ml}$ of a trace element solution described by Pfennig \& Lippert (1966), without iron salt and EDTA. The medium was supplemented by a vitamin solution described by Sharak-Genthner et al. (1981) and 5AS ( $4 \mathrm{~mm}$ ) was added as the sole carbon and energy source. Pseudomonas acidovorans was grown in the same mineral medium as used for strain BN9, but with gentisate ( $2 \mathrm{mM})$ as the carbon source. For some experiments bacteria were grown in nutrient broth (Difco).

Analytical methods. 5-Aminosalicylate (5AS) and its metabolites were analysed by ion-pair reverse-phase HPLC (HPLC data and chromatography control station model 840 , equipped with a programmable multi-wavelength detector model 490; Waters Associates). A reverse-phase column (125 mm $\times 4.6 \mathrm{~mm}$ i.d.; Bischoff $)$, packed with $5 \mu \mathrm{m}$ particles of LiChrospher $100 \mathrm{RP}-8$ (Merck), was used. The solvent system was $90 \%$ water $/ 10 \%$ methanol (v/v) and tetra- $n$ butylammonium phosphate as the ion-pair reagent (low-UV PIC A; Waters). The usual flow-rate was $0.8 \mathrm{ml} \mathrm{min}^{-1}$. The separated compounds were detected photometrically by simultaneous measurement at 210 and $350 \mathrm{~nm}$.

Ammonia was determined using glutamate dehydrogenase according to Da Fonseca-Wollheim et al. (1974). Cell-free extracts were dialysed for $3 \mathrm{~h}$ against a 1000 -fold volume of sodium/potassium phosphate buffer $\left(25 \mathrm{~mm}, \mathrm{pH} 7 \cdot 4,4^{\circ} \mathrm{C}\right)$ before the release of ammonia from 4 amino-6-carboxy-2-oxo-hexa-3,5-dienoate (ACOHDA) was assayed. This treatment removed ammonia from the cell-free extracts without affecting the relevant enzyme activities.

Molar absorption coefficient of trans-ACOHDA. Different amounts of trans-ACOHDA were dissolved in $1 \mathrm{ml} \mathrm{Tris/HCl} \mathrm{buffer,} \mathrm{pH} 8 \cdot 0$, and $20 \mu \mathrm{l}$ cell-free extract was added $\left(2.8 \mathrm{mg}\right.$ protein $\left.\mathrm{ml}^{-1}\right)$. The decrease in $A_{350}$ was determined spectrophotometrically. After the reaction had stopped, $30 \mu \mathrm{l} 6 \mathrm{~mm}-\mathrm{NADH}$ was added. Further spectrophotometric measurements were at $340 \mathrm{~nm}$. Lactate dehydrogenase $(10 \mu \mathrm{l}$ of an 
aqueous solution $10 \mathrm{mg} \mathrm{ml}^{-1}$; Boehringer) was added and lactatedehydrogenase-dependent NADH oxidation determined. The amount of pyruvate formed from trans-ACOHDA was calculated from the difference in pyruvate concentration before and after the conversion of trans-ACOHDA by cell-free extracts. No pyruvate formation was detected in a control experiment containing only cell-free extract without the addition of trans-ACOHDA.

Preparation of cell-free extracts. Cells suspended in $50 \mathrm{~mm}-\mathrm{Tris} / \mathrm{HCl}$ buffer, $\mathrm{pH} 8.0$, were disrupted with a French press (Aminco, SLM Instruments) at $1.1 \times 10^{8} \mathrm{~Pa}$. Cells and cell debris were removed by centrifugation at $100000 \mathrm{~g}$ for $1 \mathrm{~h}$ at $4^{\circ} \mathrm{C}$.

Protein estimation and enzyme assays. The protein content of cell-free extracts was determined by the method of Bradford (1976), using bovine serum albumin as a standard. One unit of enzyme activity was defined as the conversion of $1 \mu \mathrm{mol}$ substrate $\mathrm{min}^{-1}$. For fumarylpyruvate hydrolase, the cuvettes contained $0.1 \mu \mathrm{mol}$ fumarylpyruvate in $1 \mathrm{ml} 100 \mathrm{~mm}$-Tris $/ \mathrm{HCl}, \mathrm{pH} 8 \cdot 0$. The enzyme assay was started by the addition of protein. The molar absorption coefficient $\left(\varepsilon_{340}\right)$ of fumarylpyruvate was $94001 \mathrm{~mol}^{-1} \mathrm{~cm}^{-1}$ (Tanaka et al., 1957).

For detecting trans-ACOHDA hydrolase, the reaction mixture

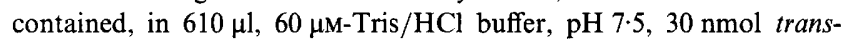
ACOHDA and $20 \mu$ of cell extract from gentisate-grown cells of $P$. acidovorans $\left[10 \mathrm{mg}\right.$ protein $\mathrm{ml}^{-1}, 0.13 \mathrm{U}$ fumarylpyruvate hydrolase $\left.(\mathrm{mg} \text { protein })^{-1}\right]$. The reaction was started by the addition of $50 \mu \mathrm{l}$ of the fraction tested, and the decrease in $A_{350}$ was measured.

Preparation of cis-ACOHDA. 5AS (15 mg) was dissolved in $100 \mathrm{ml}$ $\mathrm{Na} / \mathrm{K}$ phosphate buffer $(20 \mathrm{~mm}, \mathrm{pH} 7.5)$. The $\mathrm{pH}$ of the solution was determined using an electrode, and was periodically adjusted to $7.5-8.0$ by addition of $\mathrm{NaOH}$. Cell-free extract $(1.5 \mathrm{ml}, 7.2 \mathrm{mg}$ protein) was added and substrate turnover was analysed by HPLC. After the complete conversion of the substrate, $15 \mathrm{mg}$ solid $5 \mathrm{AS}$ and $1.5 \mathrm{ml}$ cellfree extract were added a second time. In this way $120 \mathrm{mg}$ of $5 \mathrm{AS}$ was oxidized to $c i s$-ACOHDA. Finally, $500 \mathrm{ml}$ cold ethanol was added. The mixture was centrifuged, and the pellet was discarded. Diethyl ether $(1800 \mathrm{ml})$ was added to the supernatant. This mixture was incubated at $4{ }^{\circ} \mathrm{C}$ for $12 \mathrm{~h}$ without shaking, and a yellow precipitate containing cisACOHDA was obtained. The supernatant was then decanted carefully, the yellow precipitate was redissolved in water, and the solvent was evaporated. The ring-fission product was purified by TLC $(20 \mathrm{~cm} \times$ $20 \mathrm{~cm}$ plates, $0.1 \mathrm{~cm}$ thickness, Silica Gel $60 \mathrm{PF}_{254 \mathrm{~nm}}$; Merck). The solvent system was chloroform/methanol $/ 25 \%$ (v/v) ammonia solution ( $40: 40: 20$, by vol.). The yellow ring-fission product had an $R_{\mathrm{F}}$ of 0.55 ; it was eluted with methanol and the solvent was evaporated.

Preparation of trans- $A C O H D A$. Strain BN9 was grown with 5AS $(4 \mathrm{mM})$ as sole source of carbon and energy. After complete consumption of 5AS, the culture supernatant was concentrated by evaporation. trans-ACOHDA was isolated from this solution by preparative HPLC (HPLC Pump 64, Knauer) with a Schoeffel GM 770 detector (Kratos) and an attached recorder (BD 8 multi range, Kipp \& Zonen). The signals were integrated with an Autolab System 1 (Spectra Physics). A reverse-phase column $(250 \mathrm{~mm} \times 16 \mathrm{~mm}$, Bischoff, Leonberg, Germany) packed with $5 \mu \mathrm{m}$ particles (LiChrosorb PR8; Merck) was used. The solvent consisted of $80 \%$ water $/ 20 \%$ methanol, by vol., and tetra- $n$-butylammonium phosphate as ion-pair reagent (low-UV PIC A; Waters). Fractions were collected directly behind the detector.

Protein chromatography. A fast protein liquid chromatography system (Pharmacia) was used; it consisted of two pumps (P-500), a liquid chromatography controller (LCC-500), a motor valve (MV-7), an anion-exchange column (Mono Q HR 5/5), a UV monitor (UV-1), a fraction collector (FRAC-100), and a recorder (REC-482). The anion-exchange column ( $1 \mathrm{ml}$ bed volume; Mono Q HR5/5; Phar- macia) was equilibrated with $15 \mathrm{ml} 20 \mathrm{~mm}$-Tris/ $\mathrm{HCl}, \mathrm{pH} 8 \cdot 0$. A cellfree extract from 5AS-grown cells of strain BN9 $(5 \cdot 1 \mathrm{mg}$ protein) was layered on the column. The column was washed with $5 \mathrm{ml} 20 \mathrm{mM}-$ Tris/ $\mathrm{HCl}$ buffer, $\mathrm{pH} 8.0$ and protein was eluted with $30 \mathrm{ml}$ of a linear gradient of $\mathrm{NaCl}(0-0.5 \mathrm{M}-\mathrm{NaCl})$. The flow rate was $0.8 \mathrm{ml} \mathrm{min}{ }^{-1}$. Fractions of $0.5 \mathrm{ml}$ were collected and assayed.

Gas chromatography. The following protocol was used to esterify pyruvic acid and fumaric acid (Bulletin 748G, Supelco). A sample (6 ml) was acidified to approximately $\mathrm{pH} 2$ using $0 \cdot 1 \mathrm{ml}$ aqueous $\mathrm{H}_{2} \mathrm{SO}_{4}$ $(50 \%, \mathrm{v} / \mathrm{v})$. To $1 \mathrm{ml}$ of this acidified sample were added $2 \mathrm{ml}$ methanol and $0.4 \mathrm{ml} 50 \%(\mathrm{v} / \mathrm{v}) \mathrm{H}_{2} \mathrm{SO}_{4}$; the tube was stoppered and incubated for $30 \mathrm{~min}$ at $55^{\circ} \mathrm{C}$. Then $1 \mathrm{ml} \mathrm{H} 2 \mathrm{O}$ and $0.5 \mathrm{ml}$ chloroform were added, the sample was gently inverted 20 times and centrifuged for $3 \mathrm{~min}$ at $3000 \mathrm{~g}$. A sample $(5 \mu \mathrm{l})$ of the chloroform phase was injected into a gas chromatograph (model 437A, United Technologies Packard; column: GP $15 \%$ SP- $1220 / 1 \% \mathrm{H}_{3} \mathrm{PO}_{4}$ on $100 / 120$ Chromosorb WAW, $6 \mathrm{ft} \times \frac{1}{4}$ in SS, Supelco). The injector temperature was $180^{\circ} \mathrm{C}$, the oven temperature $120^{\circ} \mathrm{C}$ and the flame ionization detector temperature was $250^{\circ} \mathrm{C}$. The flow rate was $13 \mathrm{ml} \mathrm{min}{ }^{-1}$ with nitrogen as carrier gas.

trans-ACOHDA $(0.1 \mathrm{~mm}$ in $4 \mathrm{ml} 50 \mathrm{~mm}$-Tris $/ \mathrm{HCl}, \mathrm{pH} 8.0)$ was converted by a cell-free extract from strain BN9. The sample was then treated as described above. After the conversion of trans-ACOHDA, two signals with the same retention times as the methyl esters of pyruvate $\left(R_{\mathrm{t}}=4.4 \mathrm{~min}\right)$ and fumarate $\left(R_{\mathrm{t}}=9.5 \mathrm{~min}\right)$ were detected. In contrast, these signals were not found in the original samples of transACOHDA or the cell-free extract.

Chemicals. Fumaric acid was prepared as described by Talley et al. (1959), using fumaric acid monoethyl ester as the starting material for the synthesis. Maleylpyruvate and fumarylpyruvate were enzymically prepared from gentisate as described by Stolz et al. (1992). 5-Aminosalicylate was obtained from Sigma. Fumaric acid monoethyl ester was purchased from EGA-Chemie. Gentisate was from Fluka. Other biochemicals were from Boehringer. The chemicals used for mineral salts media and buffer solutions were from Merck.

\section{Results}

Degradation of 5-aminosalicylate by cell-free extracts to L-malate, pyruvate and ammonia

Cell-free extracts from Pseudomonas sp. BN9 oxidized 5-aminosalicylate (5AS) to a metabolite with an intense UV absorption maximum at $352 \mathrm{~nm}$, previously identified as cis-4-amino-6-carboxy-2-oxo-hexa-3,5-dienoate (cis-ACOHDA; Stolz et al., (1992); Fig. 4). Further metabolism of this ring-fission product was observed only when reduced glutathione (GSH) or dithiothreitol (DTT) was added (Nörtemann et al., 1986).

A cell-free extract from strain BN9 $(0.38 \mathrm{mg}$ protein) was incubated simultaneously with $5 \mathrm{AS}(200 \mathrm{nmol})$ and GSH (200 nmol, in $1 \mathrm{ml} 100 \mathrm{~mm}$-Tris/HCl, pH 8.0). An immediate increase in absorbance $\left(\lambda_{\max }=325 \mathrm{~nm}\right.$, $\left.\Delta A_{352} \min ^{-1}=0.06\right)$ was followed by a slow turnover of cis-ACOHDA $\left(\Delta A_{352} \min ^{-1}=0 \cdot 01\right)$. When GSH was replaced by the same concentration of DTT the turnover rate of cis-ACOHDA was only $48 \%$ of the rate found with GSH.

When 5AS ( $0.2 \mathrm{~mm})$ was oxidized by cell-free extracts in the presence of GSH, $72 \%$ of the initial 5AS 
concentration was recovered as ammonia. In a control experiment, 5AS was converted by cell-free extract in the absence of GSH. As expected, the formation of the ringfission product was not accompanied by the release of ammonia.

The formation of pyruvate and L-malate from 5AS was demonstrated using specific enzyme tests (Vassault, 1985; Burlina, 1985). From the initial concentration of $5 \mathrm{AS}, 86 \%$ was recovered as pyruvate and $79 \%$ as Lmalate.

Spontaneous reactions of cis-ACOHDA in the presence of glutathione, light and acids

GSH and other thiols catalyse spontaneous cis-trans isomerizations and form addition products at carbon-carbon double bonds (Morgan \& Friedman, 1938; Lack, 1961; Seltzer \& Lin, 1979). Therefore, a purified preparation of cis-ACOHDA was incubated with GSH (1 mM) without cell-free extract. Two spontaneous reactions were observed. A rapid conversion of the substrate $\left(R_{\mathrm{t}}=8.9 \mathrm{~min}\right)$ to a new compound $\left(R_{\mathrm{t}}=\right.$ $6.8 \mathrm{~min}$ ) was detected by HPLC. This product was not detected in the absence of GSH (Fig. 1b). The in situ spectrum of the reaction product showed an absorption maximum at $355 \mathrm{~nm}$. When the same reaction was assayed spectrophotometrically, the absorption maximum shifted slowly to $320 \mathrm{~nm}$ (Fig. $1 a$ ). It was shown by HPLC that this slow reaction was connected with a turnover of the product formed in the quick reaction. DTT (1 mM) could replace GSH in both reactions. The reaction rate with DTT was only half that observed with GSH. Oxidized glutathione (GSSG) did not show any effect. The product with an absorption maximum at $320 \mathrm{~nm}$ was most probably the addition product of glutathione with ACOHDA. Similar products have been described for the reaction of glutathione with fumarylpyruvate and fumarylacetone (Lack, 1961; Seltzer \& Lin, 1979). The conversion of the ring-fission product to the new compound with an absorption maximum at $355 \mathrm{~nm}$ was also catalysed by light in the absence of GSH. cisACOHDA $(70 \mu \mathrm{M}$ in $100 \mathrm{~mm}$-Tris/ $\mathrm{HCl}, \mathrm{pH} \mathrm{8.0)}$ was incubated in a cuvette for $4 \mathrm{~h}$ in the sunlight, and was completely converted to the new compound. No reaction was detected in a control experiment protected from the light.

During the acid-catalysed transformation of cisACOHDA to fumarylpyruvate, an intermediate was formed which was tentatively identified as transACOHDA (Stolz et al., 1992). The product formed from cis-ACOHDA in the presence of light and GSH (or DTT) was shown by HPLC retention times and in situ spectra to be identical with the intermediate formed in the course of the acid-catalysed reaction.
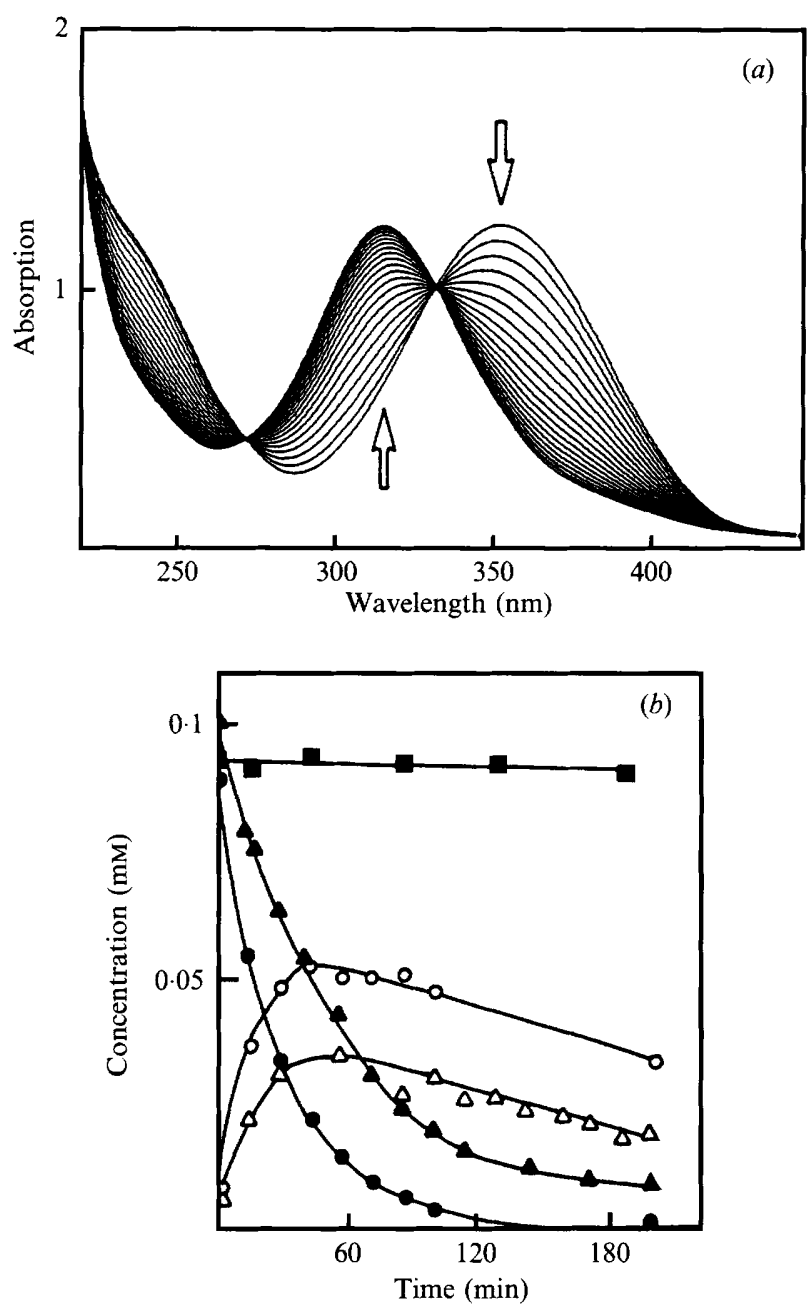

Fig. 1. Spontaneous reaction of $c i s$-ACOHDA with GSH (or DTT). (a) Overlay spectra, recorded every 20 min. Arrows indicate absorption maxima. The cuvette contained, in a total volume of $1 \mathrm{ml}, 100 \mu \mathrm{mol}$ Tris/HCl, pH 8.0, $0 \cdot 1 \mu \mathrm{mol} c i s-A C O H D A$ and $1 \mu \mathrm{mol} \mathrm{GSH.} \mathrm{(b)} \mathrm{HPLC}$ analysis. The reaction mixtures contained, in a total volume of $200 \mu \mathrm{l}$, $20 \mu \mathrm{mol}$ Tris/ $\mathrm{HCl}, \mathrm{pH} 8 \cdot 0,20 \mathrm{nmol}$ cis-ACOHDA and $200 \mathrm{nmol} \mathrm{GSH}$ (circles) or $200 \mathrm{nmol}$ DTT (triangles). As a control, cis-ACOHDA (ם) was incubated under the same conditions, but without the addition of thiols. Concentrations of cis- (filled symbols) and trans-ACOHDA (open symbols) were determined by HPLC.

\section{Isolation of trans-ACOHDA from culture supernatants}

Two metabolites absorbing at $350 \mathrm{~nm}$ were found in supernatants from 5AS-grown cultures by HPLC. They were identified by their retention times, in situ spectra and enzymic conversion as cis- and trans-ACOHDA. After growth of strain BN9 with 5AS (4 mm) as sole source of carbon and energy, about $40 \mu \mathrm{M}$-cis-ACOHDA and $20 \mu \mathrm{M}$-trans-ACOHDA were found in the culture fluid after complete turnover of 5AS. trans-ACOHDA was purified from the culture supernatant by preparative HPLC (see Methods). At pH 8, trans-ACOHDA had an absorption maximum at $355 \mathrm{~nm}$. At $\mathrm{pH} 1$, the absorption 


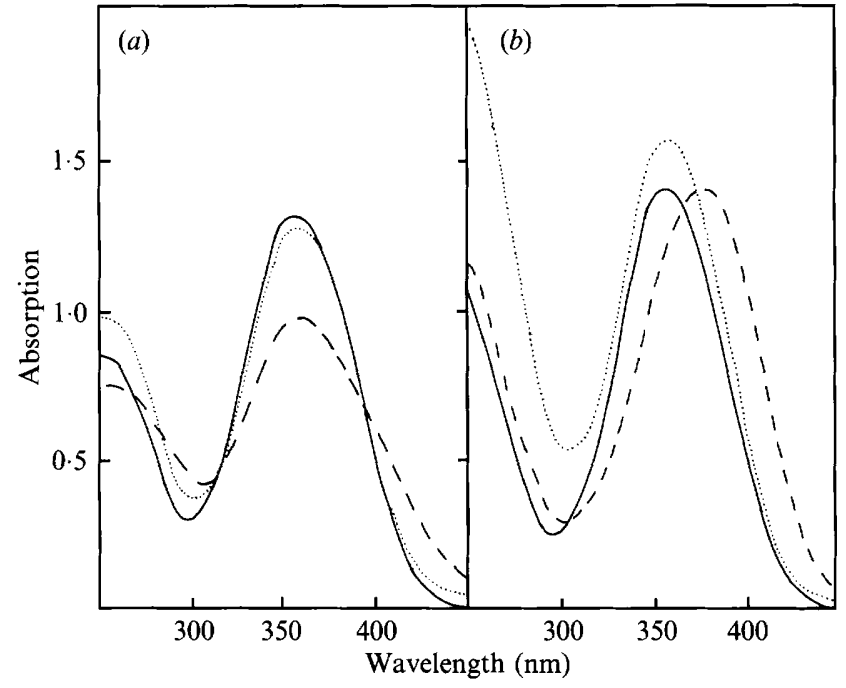

Fig. 2. Absorption spectra of cis (a) and trans- (b) ACOHDA at pH 1 $(--), \mathrm{pH} 8(-)$ and $\mathrm{pH} 13(\cdots)$ ) cis-ACOHDA was purified by preparative TLC and trans-ACOHDA by preparative HPLC (see Methods). The compounds were mixed with the required amounts of acid $(\mathrm{HCl})$ or base $(\mathrm{NaOH})$ and a spectrum was recorded immediately.

maximum shifted to $380 \mathrm{~nm}$. This bathochromic shift was not found with the cis isomer (Fig. 2). At pH 2, the half-lives for cis- and trans-ACOHDA were $29 \mathrm{~min}$ and 95 min, respectively. Fumarylpyruvate was identified as the reaction product by its UV spectrum and its HPLC retention time. The deamination of trans-ACOHDA to fumarylpyruvate proceeded by the formation of three isosbestic points, at $346 \mathrm{~nm}, 278 \mathrm{~nm}$ and $231 \mathrm{~nm}$.
Enzymic conversion of trans-ACOHDA to fumarate and pyruvate

When trans-ACOHDA was incubated with cell-free extract from strain BN9 grown with 5AS $A_{350}$ decreased almost to zero. The disappearance of trans-ACOHDA was accompanied by the formation of two new HPLC signals. The retention times of these two compounds ( $3 \cdot 4$ and $4.9 \mathrm{~min}$ ) were identical with those of pyruvate and fumarate. Maleate could be clearly distinguished by its retention time $(4.2 \mathrm{~min})$ from fumarate. When maleate $(100 \mu \mathrm{M})$ was incubated with the same crude extract for $30 \mathrm{~min}$, no isomerization to fumarate was found. The formation of fumarate and pyruvate from transACOHDA was confirmed by GC of the methyl esters (see Methods). The amount of pyruvate formed always correlated with the initial concentration of transACOHDA. The $\varepsilon_{350}$ of trans-ACOHDA was determined to be $139001 \mathrm{~mol}^{-1} \mathrm{~cm}^{-1}$.

\section{Formation of fumarylpyruvate from trans-ACOHDA}

Theoretically, there are two different pathways which result in the formation of pyruvate, fumarate and ammonia from trans-ACOHDA. One possibility is the hydrolytic cleavage of trans-ACOHDA to pyruvate and fumaramide, followed by the hydrolysis of fumaramide to fumarate and ammonia. The other possibility is the hydrolysis of the imino-function of trans-ACOHDA to fumarylpyruvate and hydrolysis of the latter to fumarate

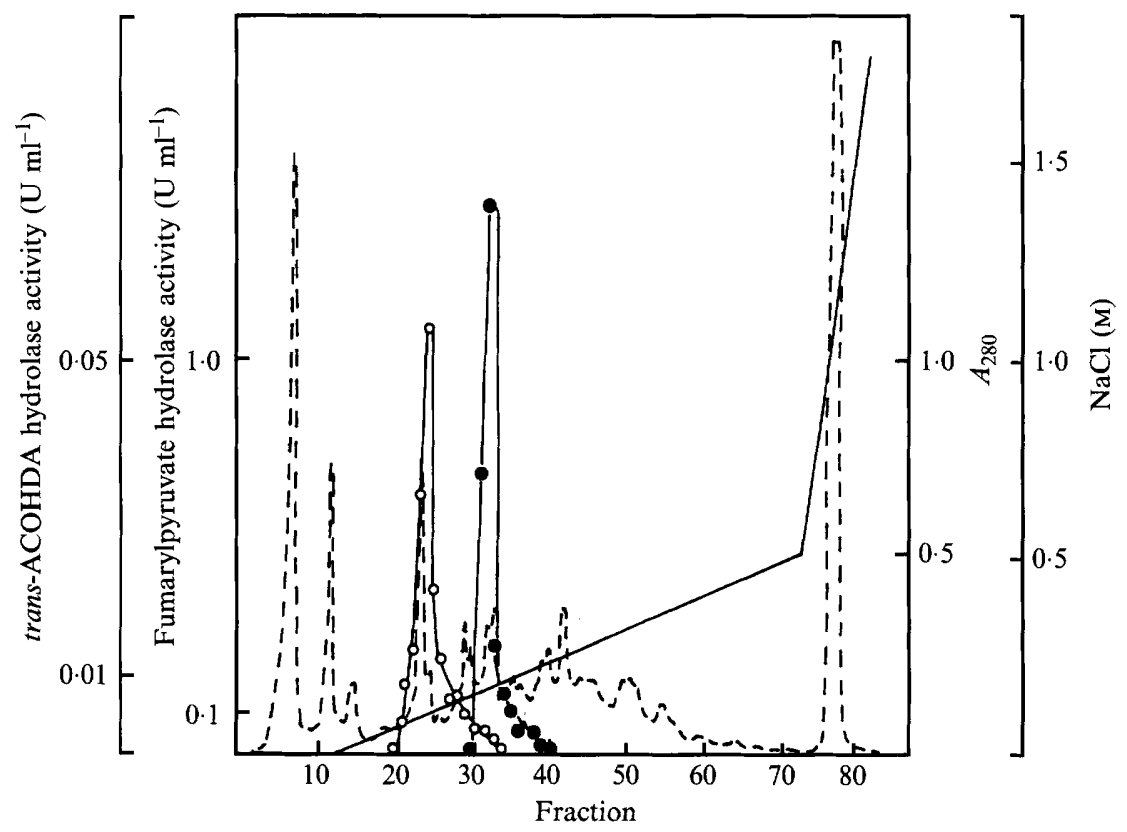

Fig. 3. elution profile from a Mono Q column of a crude extract prepared from 5AS-grown cells of strain BN9. trans-ACOHDA hydrolase $(\bigcirc)$ and fumarylpyruvate hydrolase $(\mathbf{O})$ activities were measured. The protein content was determined as $A_{280}(-D)$. The chromatography conditions are described in Methods. 
and pyruvate. To test the first hypothesis, fumaramide $(50 \mu \mathrm{M})$ was incubated together with trans-ACOHDA $(100 \mu \mathrm{M}$; in $50 \mathrm{mM}$ potassium/sodium phosphate buffer $\mathrm{pH} 7.4$ ) with cell-free extract from strain BN9 and the turnover of the substrate(s) was analysed by HPLC. trans-ACOHDA was readily converted to pyruvate and fumarate. In contrast, fumaramide was not attacked at all and was thus excluded as an intermediate. Cell-free extracts of strain BN9 contained fumarylpyruvate hydrolase activity $\left[0.34 \mathrm{U}(\mathrm{mg} \text { protein })^{-1}\right]$. The enzymic activities with trans-ACOHDA and fumarylpyruvate were separated by column chromatography. It was hard to detect protein fractions which converted transACOHDA to fumarylpyruvate by spectrophotometric assay, because the substrate and the product showed absorption maxima at 354 and $345 \mathrm{~nm}$, respectively. Therefore, as a source of the fumarylpyruvate hydrolase, a cell-free extract from $P$. acidovorans DSM 50053 grown with gentisate was added to each fraction obtained by anion-exchange chromatography (Fig. 3). The fraction with the highest activity with trans-ACOHDA (fraction 23, Fig. 3) was incubated with trans-ACOHDA in the absence of crude extract from $P$. acidovorans. As a result, the absorption maximum shifted from $354 \mathrm{~nm}$ to $345 \mathrm{~nm}$. When a fraction containing the partially purified fumarylpyruvate hydrolase (fraction 32, Fig. 3) was added to this reaction mixture, the absorbance maximum at $345 \mathrm{~nm}$ disappeared completely. No activity was observed when the fumarylpyruvate hydrolase activity alone was incubated with trans-ACOHDA in the absence of other components of the crude extract. The conversion of trans-ACOHDA to fumarylpyruvate by fraction 32 was also shown by HPLC. The second product from the hydrolysis of trans-ACOHDA was ammonia. Different concentrations of trans-ACOHDA $(40-140 \mu \mathrm{M})$ were incubated with the most active fraction from the column chromatography. The amounts of fumarylpyruvate and ammonia formed were strictly dependent on the initial concentration of the substrate. For all concentrations, we recovered equimolar amounts of fumarylpyruvate and $80-100 \%$ of the calculated amount of ammonium ion. After growth of strain BN9 with 5AS, the specific activities of cell-free extracts with trans-ACOHDA were $0 \cdot 12-0 \cdot 15 \mathrm{U}$ (mg protein $)^{-1}$. After growth with acetate or nutrient broth, the specific activity of trans-ACOHDA hydrolase was less than $0.005 \mathrm{U}(\mathrm{mg} \text { protein })^{-1}$.

\section{Discussion}

Aromatic amines are produced on a large scale by the chemical industry. They are used as intermediates in the production of drugs, dyes, pesticides and various other chemicals. Furthermore, they have been found as intermediates in the metabolism of azo dyes, aminonaph- thalenesulphonic acids, and nitro-substituted aromatic compounds under both aerobic and anaerobic conditions (Durham, 1958; Cartwright \& Cain, 1959; Wheeler et al., 1975; Hallas \& Alexander, 1983; Nörtemann et al. 1986; Rafii et al., 1990; Haug et al., 1991; Schackmann \& Müller, 1991; Chung et al., 1992). Certain aromatic amines, as (substituted) benzidine(s) or naphthylamine(s), are carcinogenic (Weisburger \& Weisburger, 1966). There is therefore considerable interest in the microbial degradation of this class of aromatic compounds. 5-Aminosalicylate was identified as an intermediate in the bacterial degradation of aminonaphthalenesulphonates and related azo dyes (Nörtemann et al., 1986; Haug et al., 1991). Furthermore, it is the active agent in many drugs for the treatment of human ulcerative colitis (Peppercorn \& Goldman, 1972; Khan et al., 1977; Dull et al., 1987; Tjørnelund et al., 1989).

Fig. 4 shows the proposed degradative pathway for the aerobic bacterial metabolism of 5AS. It involves two enzymes which were specifically induced after growth of strain BN9 with 5AS, 5AS 1,2-dioxygenase and transACOHDA hydrolase. In Pseudomonas sp. BN9, 5AS 1,2-dioxygenase was distinct from the gentisate 1,2dioxygenase (Stolz et al., 1992). Nevertheless, it was shown that the gentisate 1,2-dioxygenases from $P$. acidovorans ATCC 17438 and $P$. testosteroni ATCC 49249 also oxidized 5AS, but with significantly reduced $V_{\max }(1-7 \%)$ compared to gentisate as substrate and a high $K_{\mathrm{m}}$ (3.0-4.5 mM) (Harper \& Lipscomb, 1990a,b). 5AS 1,2-dioxygenase and gentisate 1,2-dioxygenases obviously oxidize 5AS to the same product (Harper \& Lipscomb, 1990b; Stolz et al., 1992). 5AS 1,2-dioxygenase resembles gentisate 1,2-dioxygenase in various aspects (Crawford et al., 1975; Stolz, 1989; Stolz et al., 1992). This suggests that 5AS 1,2-dioxygenase may be evolutionarily related to gentisate 1,2-dioxygenase. This could explain that it is easy to isolate pure cultures from the environment that degrade 5AS. In contrast we were unable to isolate bacteria that grow with 3- or 4aminosalicylate (unpublished results).

Unfortunately, we could not detect any enzyme activity in crude extracts that converted cis-ACOHDA to the trans-isomer. This could be due to the instability of this activity in a cell-free system, wrong assay conditions or a lack of such an enzyme in the strain. The spontaneous isomerization of the ring-fission product in the presence of thiols demonstrated that the last of these was possible. The non-enzymic isomerization of maleylpyruvate to fumarylpyruvate and maleylacetone to fumarylacetone has been reported (Lack, 1961; Seltzer \& Lin, 1979). Nevertheless, the excretion of transACOHDA by strain BN9 growing with 5AS and the induction of a trans-ACOHDA hydrolase after growth of strain BN9 with 5AS suggested that trans-ACOHDA 
<smiles>Oc1ccc(N=[As])cc1C(O)O</smiles>

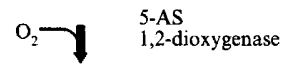<smiles>CCOCCNc1ccc(O)cc1C(=O)O</smiles>

$\downarrow+$ R-SH (spontaneous)<smiles>CCCCCCCCCCCCCCCCCC(=O)O</smiles>

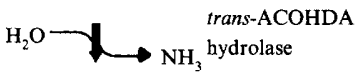<smiles>O=C(O)C=CC=CC(=O)O</smiles>

$\mathrm{H}_{2} \mathrm{O} \longrightarrow \begin{aligned} & \text { Fumarylpyruvate } \\ & \text { hydrolase }\end{aligned}$

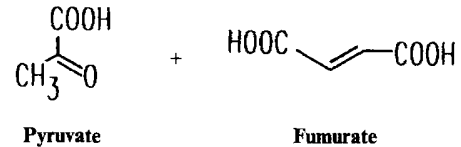

Fig. 4. Proposed pathway for the degradation of 5-aminosalicylate by Pseudomonas sp. BN9.

was a natural metabolite in the degradation of 5AS by strain BN9. trans-ACOHDA hydrolase was the second enzyme which was newly found during this study. Only in the eukaryotic metabolism of tryptophan has a comparable enamine intermediate been found as a product of 3-hydroxyanthranilate. This compound, $\alpha$ aminomuconate, is reductively deaminated to $\alpha$-ketoadipate (Ichiyama et al., 1965; Nishizuka et al., 1970).

The degradative pathway of 5AS converges at the stage of fumarylpyruvate with the degradative pathway for gentisate, which is used by most Gram-negative bacteria (Crawford \& Frick, 1977; Hagedorn et al., 1985). This is the first observation of the involvement of fumarylpyruvate hydrolase in a degradative pathway distinct from the gentisate pathway. Therefore, the question arises whether fumarylpyruvate hydrolase belongs to the same operon as gentisate 1,2-dioxygenase or is regulated separately.

The degradative pathway of 5AS differs from the bacterial metabolism of all other aminoaromatic compounds studied before. Aniline, methylanilines, and 2and 4-aminobenzoate are usually deaminated initially by dioxygenases, which form (substituted) catechol(s) (Durham, 1956; Taniuchi et al., 1964; Bachofer, 1976; Helm \& Reber, 1979; Aoki et al., 1983; Appel et al., 1984; Latorre et al., 1984; Raabe et al., 1984). Certain bacteria metabolize 2-aminobenzoate via 5-hydroxyanthranilate to gentisate (Ladd, 1962; Cain, 1968). Only for the metabolism of 2-aminobenzoate by the denitrifying Pseudomonas strain KB740 has a pathway via an aminated non-aromatic intermediate (2-amino-5oxo-cyclohex-1-ene-carboxyl-CoA) been found (Altenschmidt et al., 1990; Altenschmidt \& Fuchs, 1992). The present demonstration of novel degradative pathways for 2-aminobenzoate by Pseudomonas strain KB740 and 5AS by Pseudomonas sp. BN9 suggests that other aminobenzenes could also be metabolized by bacteria without the intermediate formation of $o$ - or $p$-diphenols.

\section{References}

Altenschmidt, U., Eckerskorn, C. \& Fuchs, G. (1990). Evidence that enzymes of novel aerobic 2-aminobenzoate metabolism in denitrifying Pseudomonas are coded on a small plasmid. European Journal of Biochemistry 194, 647-653.

AltensChMidT, U. \& FUCHS, G. (1992). Novel aerobic 2-aminobenzoate metabolism. Purification and characterization of 2aminobenzoate-CoA ligase, localisation of the gene on a $8-\mathrm{kbp}$ plasmid, and cloning and sequencing of the gene from a denitrifying Pseudomonas sp. European Journal of Biochemistry 205, 721-727.

Aoki, K., Shinke, R. \& NishiRA, H. (1983). Metabolism of aniline by Rhodococcus erythropolis AN-13. Agricultural and Biological Chemistry 47, 1611-1616.

APpel, M., RaABE, T. \& Lingens, F. (1984). Degradation of $o$-toluidine by Rhodococcus rhodochrous. FEMS Microbiology Letters 24, 123-126.

BACHOFER, R. (1976). Mikrobieller Abbau von Säureanilid-Fungiziden. Zentralblatt für Bakteriologie und Hygiene. I. Abteilung Originale B 162, 153-156.

BRADFORD, M. M. (1976). A rapid and sensitive method for the quantitation of microgram quantities of protein utilizing the principle of protein-dye binding. Analytical Biochemistry 72, 248-254.

Burlina, A. (1985). Fumarate. In Methods of Enzymatic Analysis, 3rd edn, vol. VII, pp. 34-38. Edited by H. U. Bergmeyer, Weinheim, Germany: VCH

CArN, R. B. (1968). Anthranilic acid metabolism by microorganisms. Formation of 5-hydroxyanthranilate as an intermediate in anthranilate metabolism by Nocardia opaca. Antonie van Leeuwenhoek 34, 417-432.

CARTwright, N. J. \& CAIN, R. B. (1959). Bacterial degradation of the nitrobenzoic acids. 2. Reduction of the nitro group. Biochemical Journal 73, 305-314.

Chung, K.-T., Stevens, S. E. \& Cerniglia, C. E. (1992). The reduction of azo dyes by the intestinal microflora. Critical Reviews in Microbiology 18, 175-190.

Crawford, R. L., Hutton, S. W. \& Chapman, P. J. (1975). Purification and properties of gentisate 1,2-dioxygenase from Moraxella osloensis. Journal of Bacteriology 121, 794-799.

Crawford, R. L. \& Frick, T. D. (1977). Rapid spectrophotometric differentiation between glutathione-dependent and glutathione- 
independent gentisate and homogentisate pathway. Applied and Environmental Microbiology 34, 170-174.

Da Fonseca-Wollheim, F., Bergmeyer, H. U. \& Gutman, I. (1974). Ammoniak. In Methoden der enzymatischen Analyse, 3. Aüflage, Band $I$, pp. 1850-1853. Edited by H. U. Bergmeyer. Weinheim, Germany: VCH.

DuRHAM, N. N. (1956). Bacterial oxidation of $p$-aminobenzoic acid by Pseudomonas flourescens. Journal of Bacteriology 72, 333-336.

Durham, N. N. (1958). Studies on the metabolism of $p$-nitrobenzoic acid. Canadian Journal of Microbiology 4, 141-148.

Dull, B. J., Salata, K., Van Langenhove, A. \& Goldman, P. (1987). 5-Aminosalicylate: oxidation by activated leucocytes and protection of cultured cells from oxidative damage. Biochemical Pharmacology 36, 2467-2472.

Hagedorn, S. R., Bradley, G. \& Chapman, P. J. (1985). Glutathioneindependent isomerization of maleylpyruvate by Bacillus megaterium and other Gram-positive bacteria. Journal of Bacteriology 163, 640-647.

Hallas, L. E. \& AleXander, M. (1983). Microbial transformation of nitroaromatic compounds in sewage effluent. Applied and Environmental Microbiology 45, 1234-1241.

HARPER, M. R. \& LiPSCOMB, J. D. (1990a). Gentisate 1,2-dioxygenase from Pseudomonas. Purification, characterization and comparison of the enzymes from Pseudomonas testosteroni and Pseudomonas acidovorans. Journal of Biological Chemistry 265, 6301-6311.

HARPER, M. R. \& LIPSCOMB, J. D. (1990b). Gentisate 1,2-dioxygenase from Pseudomonas. Substrate coordination to active site $\mathrm{Fe}^{2+}$ and mechanism of turnover. Journal of Biological Chemistry 265, 22187-22196.

Haug, W., Schmidt, A., Nörtemann, B., Hempel, D. C., Stolz, A. \& KNACKMUSS, H.-J. (1991). Mineralization of the sulphonated azo dye Mordant Yellow 3 by a 6-aminonaphthalene-2-sulphonate-degrading bacterial consortium. Applied and Environmental Microbiology 57, 3144-3149.

HeLm, V. \& REBER, H. (1979). Investigation on the regulation of aniline utilization in Pseudomonas acidovorans strain An 1. European Journal of Applied Microbiology 7, 191-199.

IchiYama, A., Nakamura, S., Kawal, H., Honjo, T., Nishizuka, Y., Hayaishi, O. \& SeNOH, S., (1965). Studies on the metabolism of the benzene ring of tryptophan in mammalian tissues. II. Enzymic formation of $\alpha$-aminomuconic acid from 3-hydroxyanthranilic acid. Journal of Biological Chemistry, 240, 740-749.

Khan, A. K. A., Piris, J. \& Truelove, S. C. (1972). An experiment to determine the active therapeutic moiety of Sulphasalazine. Lancet ii, 892-895.

LACK, L. (1961). Enzymic cis-trans isomerization of maleylpyruvic acid. Journal of Biological Chemistry 236, 2835-2840.

LADD, J. N. (1962). Oxidation of anthranilic acid by a species of Achromobacter isolated from soil. Nature, London 194, 1099-1100.

Latorre, J., Reineke, W. \& Knackmuss, H.-J. (1984). Microbial metabolism of chloroanilines: enhanced evolution by natural genetic exchange. Archives of Microbiology 140, 159-165.

MorGan, E. J. \& FrIEDMAN, E. (1938). Interaction of maleic acid with thiol compounds. Biochemical Journal 32, 733-742.

NishizUKA, Y., ICHIYAMA, A. \& HAYAishi, O. (1970). Metabolism of the benzene ring of tryptophan (mammals). Methods in Enzymology 17A, 463-491.

Nörtemann, B., Baumgarten, J., Rast, H. G. \& Knackmuss, H.-J. (1986). Bacterial communities degrading amino- and hydroxynaphthalene-2-sulphonates. Applied and Environmental Microbiology 52, 1195-1201.

Peppercorn, M. A. \& Goldman, P. (1972). The role of intestinal bacteria in the metabolism of salicylazosulphapyridine. Journal of Pharmacology and Experimental Therapeutics 181, 555-562.

PFenNig, N. \& LipPerT, K. D. (1966). Über das Vitamin B $_{12}$-Bedürfnis phototropher Schwefelbakterien. Archiv für Mikrobiologie 55, 245256.

RaABE, T., APPel, M. \& Lingens, F. (1984). Degradation of $p$-toluidine by Pseudomonas testosteroni. FEMS Microbiology Letters 25, 61-64.

Rafil, F., Franklin, W. \& Cerniglia, C. E. (1990). Azoreductase activity of anaerobic bacteria isolated from human intestinal microflora. Applied and Environmental Microbiology 56, 2146-2151.

SCHACKMANN, A. \& MÜLlER, R. (1991). Reduction of nitroaromatic compounds by different Pseudomonas species under aerobic conditions. Applied Microbiology and Biotechnology 34, 809-813.

Seltzer, S. \& Lin, M. (1979). Maleylacetone cis-trans-isomerase. Mechanism of the interaction of coenzyme glutathione and substrate maleylacetone in the presence and absence of enzyme. Journal of the American Chemical Society 101, 3091-3097.

Sharak-Genthner, B. R., Davies, C. L. \& Bryant, M. P. (1981). Features of rumen and sewage sludge strains of Eubacterium limosum, a methanol- and $\mathrm{H}_{2}-\mathrm{CO}_{2}$-utilizing species. Applied and Environmental Microbiology 42, 12-19.

STOLZ, A. (1989). Metabolismus von Amino- und Hydroxysalicylsäuren durch einen Bakterienstamm der Gattung Pseudomonas. PhD thesis, University of Stuttgart, Stuttgart, Germany.

Stolz, A., NörtemanN, B. \& KNackmuss, H.-J. (1992). Bacterial metabolism of 5 -aminosalicylic acid. Initial ring cleavage. Biochemical Journal 282, 675-680.

Talley, E. A., FitzPatrick, T. J. \& PorTer, W. L. (1959). Formation of fumaramic acid from asparagine in phosphate buffer. Journal of the American Chemical Society 81, 174-175.

Tanaka, H., SugiYama, S., Yano, K. \& Arima, K. (1957). Isolation of fumarylpyruvic acid as an intermediate of the gentisic acid oxidation by Pseudomonas ovalis var. S-5. Bull. Journal of the Agricultural and Chemical Society Japan 21, 67-68.

Taniuchi, H., Hatanaka, M., Kuno, S., Hayaishi, O., Nakajima, M. \& KurihaRA, M. (1964). Enzymatic formation of catechol from anthranilic acid. Journal of Biological Chemistry 239, 2204-2211.

Tuørnelund, J., Hansen, S. H. \& Cornett, C. (1989). New metabolites of the drug 5-aminosalicylic acid. I. $N$-B-D-Glucopyranosyl-5aminosalicyclic acid. Xenobiotica 19, 891-899.

VASSAULT, A. (1985). Lactate dehydrogenase. UV-method with pyruvate and NADH. In Methods of Enzymatic Analysis, 3rd edn, vol. III, pp. 118-126. Edited by H. U. Bergmeyer. Weinheim, Germany: VCH.

WeisBurger, J. H. \& Weisburger, E. K. (1966). Chemicals as causes of cancer. Chemical and Engineering News 124-142.

Wheeler, L. A., Soderberg, F. B. \& Goldman, P. (1975). The relationshıp between nitro group reduction and the intestinal microflora. Journal of Pharmacology and Experimental Therapeutics 194, 135-144. 